Biocitica

\section{COMUNICAMO-NOS ADEQUADAMENTE COM OS NOSSOS PACIENTES?}

O último número da Revista Bioética do Conselho Federal de Medicina apresenta-nos um Simpósio sobre humanização no atendimento à saúde, tratando de questões muito atuais. Destacamos o texto da Profa. Maria Júlia Paes da Silva, que trata da importância da comunicação interpessoal no atendimento médico. Apresenta o homem como ser possuidor de códigos biopsicossociais e argumenta que os pacientes permanecem atentos à maneira como o profissional se faz presente na comunicação verbal e não-verbal. Salienta que não existe neutralidade nas trocas de mensagens efetuadas entre pessoas. A comunicação entre seres perceptivos tem dois componentes: o conteúdo, ou seja, o fato, a informação que se quer transmitir, e o sentimento que sempre está presente quando há interação entre duas pessoas.

Infelizmente, o modelo de ensino vigente no curso de Medicina, estruturado no início do séc. XX por Abraham Flexner, privilegia o biológico em detrimento do ser humano biográfico. Em decorrência dessa percepção marcadamente cartesiana, oferece-se aos estudantes cada vez mais conhecimentos técnicos oriundos das inúmeras disciplinas acadêmicas e as informações são apresentadas sem qualquer preocupação de síntese integradora que respeite a dimensão antropológica do paciente. Como resultado, ao término do curso, formam-se especialistas em doenças, despreparados, entretanto, para cuidar de pessoas enfermas.

Qualquer médico sabe, por experiência própria, que uma doença raramente é orgânica ou psíquica, social ou familiar. Sabe o profissional que a enfermidade é concomitantemente orgânica, psíquica, social e familiar. Quando uma pessoa procura atendimento médico, invariavelmente está buscando por cuidados que não se limitam a livrar-se de um mal-estar circunstancial. A relação médicopaciente nunca deixará de ser interação intersubjetiva experimentada por duas pessoas. Não basta, portanto, apenas habilidades técnicas, pois fundamental é acolher o enfermo em sua dimensão biopsicossocial.

Em síntese, a vinculação entre profissional de saúde e paciente, que o ato médico impõe, é resultado de dois movimentos que se completam. O paciente que procura o profissional e 0 médico que acolhe o enfermo. Ambos são qualitativamente distintos, mas Hipócrates encontrou uma única palavra para descrever este ato "philia", que pode ser traduzido como amizade, amor, solidariedade, compromisso, compaixão.

Quando se acolhe um amigo não é apenas sua presença física que recebemos, mas sim, seus sentimentos, fragilidades e fortalezas. Muito maior atenção deve merecer o paciente já que invariavelmente apresenta-se fragilizado pela enfermidade.

\section{José Eduardo de Siqueira}

\section{Referência}

I. Silva MJP. O papel da comunicação na humanização da atenção à saúde. Bioética 2002; 10(2):73-88.

\section{Cancerdogia}

\section{QUAL A CONDUTA NO PACIENTE} COM NEOPLASIA PULMONAR DE CÉLULAS NÄO PEQUENAS E METÁSTASE CEREBRAL ÚNICA?

O diagnóstico de metástases cerebrais em um paciente portador de câncer traz consigo um grande espectro de eventos negativos que vão dos déficits neuro-cognitivos à piora significativa da expectativa de tempo de sobrevida. A escolha do tratamento mais adequado para cada paciente depende de fatores clínicos e biopsicossociais e pode ser restrito a suporte clínico e medicamentoso com corticosteróides e anticonvulsivantes (sobrevida mediana variando de um a três meses), radioterapia de cérebro total (RCT) (sobrevida mediana de quatro a seis meses) e radiocirurgia (RC) ou neurocirurgia (NC) (sobrevida mediana de nove meses em pacientes selecionados).

Aproximadamente um em cada quatro pacientes com neoplasia pulmonar não de pequenas células irá desenvolver metástases cerebrais em algum tempo da evolução de sua doença. Além dos cuidados clínicos gerais, o tratamento específico mais comumente utilizado é a RCT em doses variando de 30 a 40 Gy divididos em 10 a 20 frações diárias, levando na maioria das séries a uma melhora significativa do quadro neurológico. O impacto da RCT na sobrevida destes pacientes, especialmente quando associada à $\mathrm{RC}$ ou $\mathrm{NC}$, ainda não está totalmente claro e parece ser mais dependente da performance clínica do paciente e do estado da neoplasia extracraniana.

Tanto a RC como a NC controlam as lesões tratadas em mais de $90 \%$ dos casos. A escolha entre uma ou outra deve levar em conta que a RC é menos invasiva e menos onerosa e pode tratar várias lesões ao mesmo tempo, mesmo em localizações não passíveis de abordagem cirúrgica. Já a NC permite 0 diagnóstico histológico, traz alivio sintomático mais rápido e pode tratar lesões com volume superior a $30 \mathrm{~cm}^{3}$.

Concluindo, se seguirmos uma orientação mais ortodoxa, o tratamento específico seria RCT seguido ou não de RC caso haja resíduo tumoral três a quatro semanas após o término deste tratamento. Alternativamente, está também correto proceder a NC ou RC seguida de RCT programada ou de resgate (após recidiva ou aparecimento de novas lesões em SNC).

\section{Eduardo Weltman}

\section{Referências}

I. Noel G, Medioni J, Valery CA, Boisserie G, Simon JM, Cornu P, et al. Three irradiation treatment options including radiosurgery for brain metastases from primary lung cancer. Lung Cancer 2003; 41:333-43.

2. Zabel A, Miker-Zabel S, Thilmann C, Zuna I, Rhein B, Wannenmacher M, Debus $L$. Treatment of brain metastases irradiation in patients with non-small cell lung cancer (NSCLC) by stereotactic linacbased radiosurgery: prognostic factors. Lung Cancer 2002; 37:87-94.

3. Rodrigus P, Brouwer P, Raaymakers E. Brain metastases and non-small cell lung cancer. Prognostic factors and correlation with survival after irradiation. Lung Cancer 2001; 32:129-36.

4. Kim SY, Kondziolka D, Flickinger JC, Lunsford LD. Stereotactic radiosurgery for patients with nonsmall cell lung carcinoma metastatic to the brain. Cancer 1997:80:2075-83. 